\title{
International Asian Cinemas Festival Vesoul 2010
}

\author{
By Gönül Dönmez-Colin
}

Spring 2010 Issue of KINEMA

\section{6th INTERNATIONAL ASIAN CINEMAS FESTIVAL VESOUL}

Started sixteen years ago by ambitious lovers of cinema, Martine and Jean-Marc Thérouanne, the International Asian Cinemas Festival of Vesoul (FICA, 26 January-2 February 2010) has become one of the most important festivals in Europe and especially in France on the cinemas of the Asian countries. The $16^{\text {th }}$ edition took place between 26 January- 2 February 2010 this year with a focus on Turkey, Taiwan and Vietnam. In this context, a special retrospective was devoted to Ömer Kavur (1944-2005), the truly auteur filmmaker of Turkey. All fiction features of Kavur including classics such as Motherland Hotel were screened for the first time in France, to the enthusiastic audiences that travelled far to this otherwise quiet town near the Swiss border.

Sixty years of Taiwanese cinema that stretched from 1949 to 2009 was presented with eighteen films that included lesser-known names (Vivian Chang, Hidden Whisper; Yee Chih-yen, Blue Gate Crossing; Chung Mong-hong, Parking) along with masters Hou Hsiao Hsien (City of Sadness), Tsai Ming-liang (Goodbye Dragon Inn) and Edward Yang (That Day on the Beach, Yiyi). From Vietnam, a less publicized aspect of the film industry, the documentaries were in the program.

The president of the international jury was Wan Jen (Super Citizen Ko) from Taiwan. Other members were the actress Serra Ylmaz from Turkey (known in the West with her roles in the films of Ferzan Özpetek, Hamam, Harem, et al); Aruna Vasudev, one of the most distinguished names of Asian cinema and Iraqi filmmaker Amer Alwan (Zaman, the Reed Man). Netpac (Network for Promoting Asian Cinema) founded by Aruna Vasudev 20 years ago and Guimet, the Asian Arts Museum in Paris (Emile Guimet award) had their juries in addition to the Youth Jury and the jury of the Oriental Languages. The People's award was also among the significant prizes.

The nine films in competition were films that were not previously released in France. From Turkey, Selda Çiçek's first film, Not Worth a Fig Seed about the sad consequences of being born a woman in the south east of the country; from Hong Kong Anne Hui's Night and Fog, a drama on wife abuse; from India Satish Manwar's Damned Rain about farmer suicides in India; from China Guan Hu's tragic-comic, Cow about the Japanese occupation of the country; from South Korea Jeon Kyu-hwan's Animal Town about loneliness in a metropolis were noteworthy works.

From Indonesia, human rights activist and playwright Ratna Sarumpaet's first film, Jamila and the President about child prostitution in her country turned out to be rather controversial since some of the jury members could not accept that the heroine never gave up on religion after so many blows although it was pretty clear in the film that belief in Allah is not only religious devotism but also part of the culture in Indonesia as in several other Muslim countries and does not mean endorsement of organized religion, which Jamila condemns in her last speech before execution. Christine Hakim, who gave her support to the film, was remarkable as the prison guard torn between her emotions, prejudices and duties. Iranian expatriate Babak Jalali was between Bruno Dumont and Béla Tarr in Frontier Blues, human portraits in a landscape forgotten by time. From Taiwan, No puedo vivir sin ti (only a Spanish title was given) by Leon Dai touched the hearts of the spectators with an ordinary story of a father losing custody of her daughter, rendered in a not-so-ordinary manner.

Among the documentaries in competition, Supermen Of Malegaon by Faiza Ahmad Khan (India) was a hilarious tale of the relationship between Indian people and cinema, and between Indian cinema and the West, told with sensitive humour that highlighted the human aspect.

In the thematic section of the festival were films that highlighted men's relation to nature keeping in mind a dialogue between the East and the West. Some of the unforgettable films that were a delight to see again 
were Dersu Uzala (Akira Kurosawa), Days and Nights in the Forest (Satyajit Ray), Mongolian Ping Pong (Ning Hao) and Clouds of May (Nuri Bilge Ceylan).

Not to forget the young public, Iranian Farhad Mehranfar's Paper Airplanes and Japanese Isaho Takahata's Panda, Little Panda were also included in the program.

From Iran, filmmaker Jafar Panahi and actress Fatamed Motamed Arya were invited to receive the Golden Cyclo Honour prize for their struggles in the name of freedom. Jafar Panahi could not be present as the Iranian government refused to grant him the exit visa. (Some weeks later, he and his family, along with his house guests, were arrested with the charges of conspiring to make a film against the government.) Aruna Vasudev received the medal to the city of Vesoul for her immense contribution to Asian cinema.

The festival opened with Weaving Girl by Wang Quan'an from China, the winner of the Golden Bear at the Berlin Film Festival in 2007 with his previous film, Tuya's Marriage and closed with The Season of the Horse by Ning Cai (China).

\section{References}

\section{Awards}

Golden Cyclo Award (ex aequo)

No Puedo Vivir Sin ti by Leon Dai (Taiwan)

COW by Guan $\mathrm{Hu}$ (China)

International Jury Grand Prix:

The Damned Rain by Satish Manwar (India)

Special Mention: Animal Town by Jeon Kyu-hwan (Korea)

\section{NETPAC Award}

Animal Town by Jeon Kyu-hwan (Korea)

\section{Emile Guimet Award}

(by the Friends of National Museum of Asian Arts of Paris)

No Puedo Vivir Sin Ti by Leon Dai (Taiwan)

Guimet Special Favourite: Supermen of Malegaon by Faiza Ahmad Khan (India),

INALCO Jury Award (by the National Institute of Oriental Languages and Civilisations, Paris)

The Pawn Shop by Milo Sogueco (Philippines)

Special Langues 'O' Favourite: the Damned Rain by Satish Manwar (India)

Audience Award for feature film

Jamila and the President by Ratna Sarumpaet (Indonesia).

Audience Award for documentary film

The Kite Player by Jean-Paul Mignot (Afghanistan-France).

Youth Award

Supermen of Malegaon by Faiza Ahmad Khan (India).

High schools Award

"Jamila and the President" by Ratna Sarumpaet (Indonesia).

\section{Author Information}

Gönül DÖNMEZ-COLIN is an independent researcher and writer whose publications include Women, Islam and Cinema, Cinemas of the Other: A personal Journey with Filmmakers from the Middle East and Central Asia, Cinema of North Africa and the Middle East (ed.); Turkish Cinema: Identity, Distance and Belonging (Reaktion Books), and Routledge Dictionary of Turkish Cinema (2014). 